\title{
A Striking Diploid Male Frequency in a Less Suitable Environment: The Future of the Orchid Bee Euglossa Annectans
}

\author{
Wilson Frantine-Silva ${ }^{1, *}$, Maria Cristina Gaglianone ${ }^{1}$ and Silvia Helena Sofia ${ }^{2}$ \\ 1 Universidade Estadual do Norte Fluminense Darcy Ribeiro, CBB, Laboratório de Ciências Ambientais, \\ PPG-ERN. Avenida Alberto Lamego 2000, Campos dos Goytacazes, RJ - Brazil; mcrisgag@uenf.br \\ 2 Universidade Estadual de Londrina, CCB, Departamento de Biologia Geral. Rodovia Celso Garcia Cid Km \\ 480 Campos Universitário, Londrina, PR-Brazil; shsofiabelh@gmail.com \\ * Correspondence: wilsonfranine@gmail.com; Tel. : +55-439-929-0927
}

\begin{abstract}
Climate change and deforestation have figured among the main causes of the pollinators' decline. Especially for bees, the resulting losses of genetic diversity might cause higher levels of nonviable diploid male production, compromising population survival. Herein we evaluate the impact of both climate change and genetic diversity on the present and future of the orchid bee Euglossa annectans Dressler, 1982. We estimated the frequency of diploid males in 359 individuals using eight microsatellite loci. We also build ecological niche models based on 71 occurrence points to project the environmental suitability over time from the past $21 \mathrm{Ka}$ towards 2050 considering the IPCC - RCP 4.5 scenario. We confirmed a diploid male frequency in E. annectans 10-folds higher than any other report for orchid bee species. The niche models also indicate an average reduction of $45.12 \%$ in suitable areas for the last $21 \mathrm{Ka}$ and $36.34 \%$ up to 2050 . Considering the species trend to diploid male production and the projected reduction of suitable area, we strongly recommend connecting and monitoring relictual populations as a strategy to increase the species potential distribution area.
\end{abstract}

Keywords: Euglossini; Climate change; Pollinator decline; Genetic Diversity; Conservation

\section{Introduction}

Climate change has imposed a matrix of different impacts and challenges to pollinators[1] such as decupling plant-pollinator mutualism, shifts in phenology, and species range [1,2]. Since the climate is one of the most important factors of large-scale species distributions, climate change may trigger numerous unpredictable ecological consequences [3]. Several studies have shown that bee populations decline can be attributed to climate change [3,4], which is even acting by increasing the frequency of extreme events or gradually changing average conditions. Some recent extinctions events may have also been caused by such climatic fluctuations as those from the Last Glacial Maximum (LGM hereafter) to nowadays [5]. These changes are not negligible and coupled with habitat loss and fragmentation from the deforestation process might be catastrophic for forestdependent pollinators in the future $[1,6]$.

Modern methods might guide species conservation and evaluate the effects of climate change on species distributions, such as ecological niche models (ENM). These ENMs statistical frameworks use species records and available predictor variables to calculate and project environmental suitability over space and time [7]. This information has been successfully used for determining pollinators' species range in past, present and future scenarios with different conservation outcomings for pollinators, especially bees $[2,8,9]$. 
Bees are haplodiploid arrhenotokous organisms in which the heterozygosity at the complementary sex-determination locus (CSD) is widely distributed as the genetic rule for female development [10]. Lower levels of genetic diversity might result in higher levels of diploid male production [11]. These diploid males are usually inviable or sterile [12] which decreases the population reproductive fitness, increases colony mortality, or decreases colony growth rates in social species [13]. Natural populations usually maintain sufficient alleles at the CSD locus to keep diploid males at irrelevant frequencies $[13,14]$. However, external pressures and environmental disturbances may cause significant changes to the mutation-drift equilibrium in a way that the population may become prone to diploid male extinction vortex [12,13].

Despite such odds, the order Hymenoptera thrived as one of the most diversified insect groups[15]. Therefore, it is predictable that evolutionary mechanisms and strategies have been selected to mitigate the effects of diploid male production [16]. For instance, orchid bees (Apidae: Euglossini), a neotropical group about of 240 species [17], have evolved under a male-biased dispersal strategy [18] wherein males became able to fly astonishing distances [19] promoting gene flow. Such a dispersal ability can drastically reduce the influence of a small number of alleles in the diploid male production [20,21]. In fact, there is some support for low levels of diploid males in orchid bees [22,23], but a newer assessment says otherwise [24], highlighting that some species may be more prone to maintain higher rates of diploid male production, as in the case of E. annectans.

Euglossa annectans is an orchid bee species endemic to the Brazilian Atlantic Forest (one of the most highly threatened hotspots in the world [25]) quite associated with the inland Seasonal Semideciduous Forests (SSF). This species is an important tropical pollinator related to at least 24 Angiospermae families [26]. Just like other euglossine species, E. annectans is on the edge of the solitary-social behavior, nesting either alone or with more than one female [27] forming aggregates as large as 27 females and 259 cells for as long as five years [28]. Populations of E. annectans seem to be especially susceptible to diploid male production. Frequencies around $10 \%$ have been found for the species [24], considerably higher than any other record for orchid bees measured with microsatellite markers [22-24]. Microsatellites (simple sequence repeats) markers have been used as a stable proxy of diploid male production since it is based on polymerase chain reaction (PCR).

Considering such concerns on both, the species and its environment, we evaluate herein the forecast climate change effects on the potential geographical distribution of the orchid bee $E$. annectans, as well as its diploid male production addressing multiple questions. At first, we ask whether are there populations under risk by either or both future shifts on climate suitable areas and/or high diploid male production? Second, will climatically suitable areas for E. annectans reduce or extend within the Atlantic Forest domain? Responding to such questions will help us to better understand the impacts of climate change on E. annectans in the forthcoming years as well as to plan conservation measurements.

\section{Experiments}

\subsection{Bee sampling and occurrence data}

Twelve remnants at the southern Atlantic Forest were sampled to capture males from E. annectans covering about 280,000 $\mathrm{km}^{2}$ of the known species distribution. Males of orchid bees are attracted by synthetic scent baits; hence we used the following set: benzyl acetate, benzyl benzoate, beta-ionone, eucalyptol, eugenol, methyl cinnamate, methyl salicylate, and vanillin. Samplings were performed from December 2008 to March 2015 from 5 am to $4 \mathrm{pm}$. The additional occurrence data were extracted from the literature, the Zoology Museum of the Universidade Estadual de Londrina, and from the SpeciesLink database (Frantine-Silva, under review). Sampling points and occurrence points gathered from the literature are represented in Figure 1. 


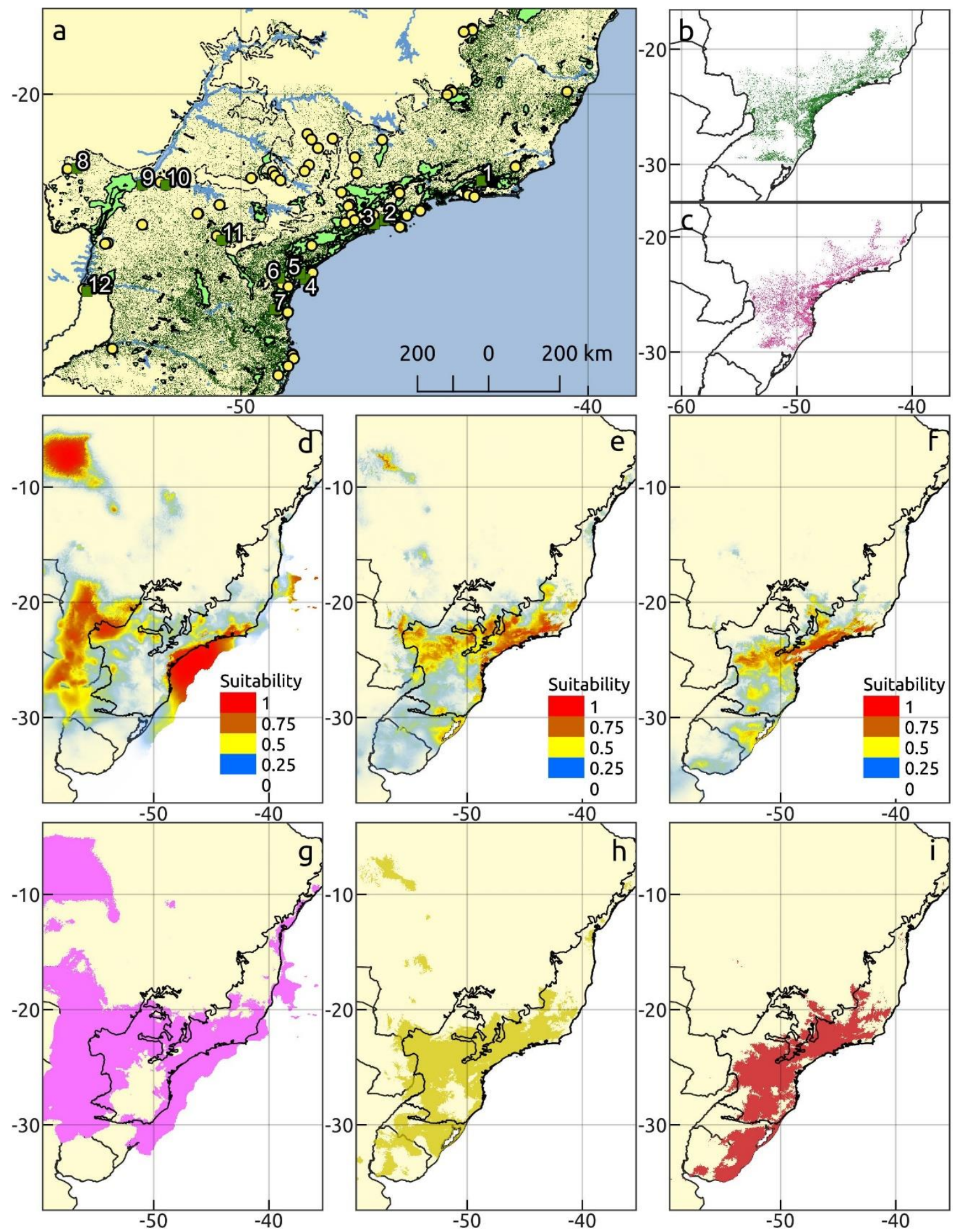

Figure 1. Map of occurrence and suitable areas for Euglossa annectans in Brazilian Atlantic Forest (AF). (a) Yellow dots represent known occurrences; green squares and numbers correspond to the sampling locations (see the text); dashed line AF original area; dark-greenish area represents current $\mathrm{AF}$ fragments; light green polygons depict legally protected areas. (b) AF fragments over current suitable areas; (c) suitable AF fragments over 2050 projection. Suitability (d-f) and occurrence maps (g-i) for Euglossa annectans; (a) and (d) Last Glacial Maximum; (b) and (e) Current; (c) and (f) 2050 projection.

\subsection{Climatic variables and Ecological Niche Models}

We used a set of 19 bioclimatic variables from three General Circulation Models (GCM) the CCSM4, the MPI-ESM, and the MIROC-ESM from the Worldclim repository (www.worldclim.org)

The 1st International Electronic Conference on Biological Diversity, Ecology, and Evolution, 15-31 March 2021 
[29]. Variables were downloaded at 2.5 arcminutes and further cut between latitude 5 and -35 , and longitude -73 and - 34 under the datum WGS84. Three different strategies were used to select climatic variables: i) all 19 bioclimatic variables; ii) a set of ecologically meaningful variables for orchid bees [8]; iii) a set of filtered variables through principal component analysis. The PCA strategy resulted in a set of 11 variables comprising 95\% of the variation (in order of contribution: bio-10, 5, 14, 17, 1, 9, $19,3,12,15$, and bio-4). We also excluded the variables bio- 8 and bio-11 due to the high correlation with bio-10 and bio-9 (r2>0.8; $<<0.001)$. We evaluated the best strategy as the one with smaller values of Akaike information criterion corrected to small samples (AICc), the Bayesian information criterion (BIC), and higher log of probability $(\log L)$ in the software ENMtools [30].

The PCA strategy presented the best performance and was then selected to build the models. The models were built in the MaxEnt software v3.4.1 [31] following the program defaults, but removing duplicates, keeping $75 \%$ of occurrence for model training and $25 \%$ for cross-validation over 10 replications. We used the AUC (area under the curve) to evaluate the models. The model was then projected to different points in time. The LGM $(21 \mathrm{Ka})$ was considered to evaluate climatic stable areas since then. Likewise, a future scenario corresponding to the projection of a moderate representative cumulative pathway (RCP 4.5) was considered as a reasonable averaged expectation for the next couple of decades.

\subsection{Habitat loss and fragmentation analysis}

Occurrence maps were produced using thresholds of equal sensitivity and specificity [8]. Fragmentation indexes were then calculated for each climatic scenario using the PatchStat function of SDMTools in R [32]. This function calculates several patch indexes including size (pixels) area $\left(\mathrm{m}^{2}\right)$, core area (pixels) and perimeter (pixels). To quantify the suitable areas for E. annectans covered by forested habitat, we analyzed forest formations from high-resolution classified data (Map-Biomas repository: www.mapbiomas.org; collection 5.0) [33]. We also quantified the proportion of habitats that are still available for E. annectans at the network protection for the existing Atlantic Forest according to the IUCN's World Database (http://protectedplanet.net).

\subsection{Molecular detection of diploid males}

To assess the diploid male production, we genotyped eight microsatellite loci (Ann2, Ann3, Ann4, Ann6, Ann8, Ann24, Ann37, and Ann41; [34]) using the amplification via PCR as described by Penha et al. [35]. The statistics related to the production of diploid males (DMP) were accessed according to the protocol used by Boff et al. [23] and Giangarelli et al. [24]. We computed the probability to detect a heterozygous if diploid (Phet), the absolute number of diploid males $(n D M)$, the relative frequency of diploid $(f D M)$, and a $95 \%$ confidence interval for the $f D M$ assuming a binomial distribution using the "binom" $\mathrm{R}$ package. Descriptive genetic diversity indexes were calculated in the GeneAlex software.

\section{Results}

\subsection{Ecological niche models and habitat fragmentation}

Our niche model built from the 71 occurrence points presented a high value of AUC for both, training (0.979) and testing (0.976) procedures. Suitable areas have been changed considerably from LGM to current (CUR) scenarios, decreasing in both inland and coastal areas (Figure 1, d-e). Future (FUT) projection shows a trend to shift the suitability zone toward the south-east, near to the coastal line (Figure 1, f). Predicted distribution areas for E. annectans have been decreased since $21 \mathrm{Ka}$ to nowadays (-45.12\%; Figure 1, g-h) and will keep the trend (-36.34\%) in the forthcoming years (Figure 1 , h-i). Considering the Atlantic Forest currently left, $62.71 \%$ of E. annectans distribution is covered by some fragment (Figure 1, b) and $52.43 \%$ is under some protected area. The forested suitable habitat may decrease about $17.76 \%$ up to 2050 (Figure 1, c). 
Table 1. Fragmentation parameters estimated from binary occurrence maps for Euglossa annectans. Size, Core, and Perimeter are presented as the sum of the number of pixels. Area $\left(\mathrm{km}^{2}\right)$ is an approximation based on the median pixel size at 2.5 arc-min between 0 and -40 latitudinal degrees $\left(\sim 17.015 \mathrm{Km}^{2}\right)$. LGM: last glacial maximum; CUR: current model; FUT: 2050 projection; AF : Atlantic Forest; patches: scenarios including the current fragmentation map. Protected Areas: areas under law protection.

\begin{tabular}{lcccc}
\hline \multicolumn{1}{c}{ Scenario } & Size & Area $\left(\mathbf{K m}^{2}\right)$ & Core & Perimeter \\
\hline LGM & 157451 & $2,980,430$ & 142009 & 18216 \\
CUR & 55330 & $1,047,355$ & 43050 & 16608 \\
FUT & 35223 & 599,320 & 24003 & 11466 \\
CUR patches & 9590 & 181,532 & 563 & 93,542 \\
FUT patches & 7887 & 149,265 & 353 & 75,991 \\
AF patches & 15292 & 289,466 & 695 & 150,702 \\
Protected areas & 5028 & 95,176 & 1514 & 24,199 \\
\hline
\end{tabular}

\subsection{Diploid male production}

Three hundred ninety-eight genotyped males of E. annectans from the 12 surveyed localities resulted in 39 diploid males, a diploid male production frequency of 0.098 (95\% C.I. 0.07 - 0.13 ). All locations, excepting one (S-2), showed diploid male frequencies between 0.057 (95\% C.I. 0 - 0.19) and 0.182 (95\% C.I. $0.05-0.4)$. The probability of detecting a diploid male by heterozygosity in at least one locus (Phet) was always close to one, ranging between 0.9995 and 0.9999 , confirming the high sensibility of the data set to detect the diploid males. The number of alleles, number of effective alleles, private alleles, and gene diversity are described in Table 2.

Table 2. Diploid male production and descriptive genetic diversity index for 12 sampling locations of Euglossa annectans. S: sampling site (see Figure 1); n: number of genotyped males; DM number of detected diploid males; fDM frequency of diploid males; C195\%: 95\% confidence interval for diploid males' frequency; Phet: probability to detect a diploid male if heterozygous at one locus; $A$ : number of alleles, $e A$ : effective number of alleles, $p$ : number of privative alleles, $H$ gene diversity.

\begin{tabular}{ccccccccccccc}
\hline $\mathbf{S}$ & $\mathbf{n}$ & $\mathbf{D M}$ & $\boldsymbol{f D} \boldsymbol{M}$ & $\mathbf{C I 9 5 \%}$ & $\boldsymbol{P h} \boldsymbol{e t}$ & $\boldsymbol{A}$ & $\mathbf{s d}$ & $\boldsymbol{e A}$ & $\mathbf{s d}$ & $\boldsymbol{p}$ & $\boldsymbol{H}$ & $\mathbf{s d}$ \\
\hline 1 & 40 & 6 & 0.150 & $0.04-0.27$ & 0.9999 & 8.5 & 1.32 & 5.2 & 0.71 & 2 & 0.78 & 0.03 \\
2 & 9 & - & - & - & 0.9999 & 4.1 & 0.44 & 3.0 & 0.45 & 1 & 0.64 & 0.06 \\
3 & 22 & 4 & 0.182 & $0.05-0.40$ & 0.9998 & 5.5 & 0.93 & 3.9 & 0.55 & 0 & 0.73 & 0.05 \\
4 & 11 & 2 & 0.182 & $0.03-0.60$ & 0.9999 & 5.3 & 0.53 & 4.3 & 0.57 & 0 & 0.78 & 0.03 \\
5 & 46 & 6 & 0.125 & $0.06-0.30$ & 0.9999 & 7.1 & 0.74 & 3.7 & 0.37 & 2 & 0.72 & 0.03 \\
6 & 60 & 4 & 0.067 & $0.02-0.16$ & 0.9999 & 8.0 & 0.76 & 3.9 & 0.62 & 1 & 0.70 & 0.04 \\
7 & 35 & 1 & 0.029 & $0.00-0.15$ & 0.9999 & 7.1 & 0.97 & 4.7 & 0.82 & 5 & 0.74 & 0.05 \\
8 & 26 & 3 & 0.115 & $0.02-0.30$ & 0.9997 & 5.8 & 0.56 & 3.5 & 0.54 & 0 & 0.67 & 0.05 \\
9 & 40 & 6 & 0.150 & $0.06-0.30$ & 0.9999 & 7.9 & 1.27 & 5.1 & 0.91 & 1 & 0.77 & 0.04 \\
10 & 35 & 2 & 0.057 & $0.00-0.19$ & 0.9999 & 7.4 & 1.19 & 4.7 & 0.85 & 3 & 0.75 & 0.05 \\
11 & 60 & 4 & 0.067 & $0.02-0.16$ & 0.9995 & 9.9 & 1.63 & 5.3 & 1.01 & 1 & 0.76 & 0.04 \\
12 & 14 & 1 & 0.077 & $0.01-0.33$ & 0.9999 & 4.6 & 0.46 & 3.2 & 0.45 & 0 & 0.65 & 0.08 \\
Total & 398 & 39 & 0.098 & $0.07-0.13$ & 0.9999 & 13.7 & 5.62 & 4.2 & 0.20 & - & 0.73 & 0.01 \\
\hline
\end{tabular}

\section{Discussion}

Climate change has become an important issue for the pollinator's conservation $[1,3,36]$. Herein, we accessed the effects of climate change on past, present, and future distribution of Euglossa annectans, as well as the diploid male production as a proxy for population decline [11]. Both approaches highlighted important insights about E. annectans future. We asked whether populations 
would be at risk by climate change or by the increase of diploid male production. Our ENM showed a substantial reduction in climatically suitable areas at the western species distribution. Important natural reserves such as the Iguaçu National Park, State Park Morro do Diabo skip out of the suitable areas, leaving the coastal region as the main suitable area for the species. Although E. annectans has experienced a recent history of population reduction and expansion (Frantine-Silva et al., under review), it is worth noting that such fluctuations possibly never happened in an environment as fragmented as the current one in a such short time. Therefore, considering the ENM results, populations from the west seem to be more threatened than those at the coast.

The diploid male frequency results suggest a slightly different picture. At first, our data confirmed that Euglossa annectans shown an expressive higher frequency of diploid males than the overall orchid bees. While the diploid male frequency for the other species fluctuates between 0.01 and 0.02 [24,37], E. annectans shown values about ten times higher ( $f D M 0.098$ ). As mentioned before, the heterozygosity required to trigger the feminizer cascade in bees implicates that low levels of genetic diversity on the CSD locus will result in an increment of diploid male production [11-13]. This situation would lead to an extinction loop called "diploid male vortex" [13], typified by the increased extinction risk due to the diploid male production increasing. External pressures reduce the effective population size which increases the diploid male frequency, that further inhibits the population growth and decrease the CSD variability, resulting in more diploid males [17]. Although evolutionary mechanisms and strategies have been selected to avoid such a situation [19], in small and closed populations, the demographic and environmental stochasticity combined with increased drift and diploid male production would lead to the diploid male vortex. Despite the higher fDM documented for $E$. annectans, the observed values of the genetic diversity demonstrate levels equivalent to species with a low frequency of diploid males [22,23,35,37]. This fact would indicate some underlying adaptation to circumvent this issue, as a female-biased sexual proportion in the population or even some diploid male detection mechanism that avoids matting, but further studies should specifically address these questions.

Concerning whether E. annectans populations are at risk due to the higher diploid male production, we must be careful. The diploid male frequency has been pointed out as a proxy of bee population decline [11]. However, seemly different frequencies might mean quite similar numbers of diploid males. For instance, the $f D M$ from the two smaller samples analyzed are expressively different, but this difference represents a single diploid male observation. Nonetheless, the observed 39 diploids in 398 genotyped males still considerably higher than the overall rate estimated for orchid bees (i.e., 5 in 1034 individuals) [37]. Therefore, the high diploid male production in E. annectans and the forthcoming habitat reduction raise a conservationist alert for this species. Altogether, considering the importance of the dispersal effectiveness to maintain populations at low levels of diploid male production [20,21], connecting the forested patches seems to be the most efficient strategy for conservation.

\section{Conclusions}

Climatic suitable areas for E. annectans demonstrate a remarkable retraction at the western current distribution, maintaining the observed trend from the LMG. In addition, the 10-fold higher diploid male frequency is confirmed here as an outstanding rate of diploid male production. Both findings have undeniable consequences for the species conservation.

Acknowledgments: To Enderley Dec and Guaraci D. Cordeiro for donation of several specimens; Instituto Chico Mendes (MMA-Brazil), Instituto Ambiental do Paraná (IAP) and IF-São Paulo for the collecting permits. This study was financed by CNPq and CAPES. WFS thanks CAPES for the PNPD fellowship. MCG thanks to FAPERJ (203.321/2017) for financial support. SHS (305343/2018-1) and MCG (303894/2018-0) thank to CNPq for their fellowships.

Author Contributions: W.F.S. conceived, designed and performed the experiments; W.F.S., M.C.G. and S.H.S. analyzed the data; S.H.S. contributed with reagents and analysis tools; All the authors wrote the paper. 
Conflicts of Interest: The authors declare no conflict of interest.

\section{References}

1. Settele, J.; Bishop, J.; Potts, S.G. Climate Change Impacts on Pollination. Nature Plants 2016, 2, 1-3.

2. Rasmont, P.; Franzén, M.; Lecocq, T.; Harpke, A.; Roberts, S.P.M.; Biesmeijer, J.C.; Castro, L.; Cederberg, B.; Dvořák, L.; Fitzpatrick, Ú.; et al. Climatic Risk and Distribution Atlas of European Bumblebees; 2015; Vol. 10, pp. 1-236; Pensoft, Sofia, Bulgaria.

3. Bartomeus, I.; Ascher, J.S.; Wagner, D.; Danforth, B.N.; Colla, S.; Kornbluth, S.; Winfree, R. ClimateAssociated Phenological Advances in Bee Pollinators and Bee-Pollinated Plants. PNAS 2011, 108, 2064520649, doi:10.1073/pnas.1115559108.

4. Williams, P.H.; Araújo, M.B.; Rasmont, P. Can vulnerability among British bumblebee (Bombus) species be explained by niche position and breadth? Biol Conserv 2007, 138, 493-505, doi:10.1016/j.biocon.2007.06.001.

5. Varela, S.; Lima-Ribeiro, M.S.; Diniz-Filho, J.A.F.; Storch, D. Differential Effects of Temperature Change and Human Impact on European Late Quaternary Mammalian Extinctions. Global Chang Biol 2015, 21, 1475-1481, doi:10.1111/gcb.12763.

6. de Moraes, K.F.; Dantas Santos, M.P.; Gonçalves, G.S.R.; de Oliveira, G.L.; Gomes, L.B.; Lima, M.G.M. Climate Change and Bird Extinctions in the Amazon. PLoS ONE 2020, 15, e0236103, doi:10.1371/journal.pone.0236103.

7. Elith, J.; Phillips, S.J.; Hastie, T.; Dudík, M.; Chee, Y.E.; Yates, C.J. A Statistical Explanation of MaxEnt for Ecologists. Divers Distribut 2011, 17, 43-57, doi:10.1111/j.1472-4642.2010.00725.x.

8. Nemésio, A.; Silva, D.P.; Nabout, J.C.; Varela, S. Effects of Climate Change and Habitat Loss on a ForestDependent Bee Species in a tropical fragmented landscape. Insec Conser Divers 2016, 9, 149-160, doi:10.1111/icad.12154.

9. Frantine-Silva, W.; Giangarelli, D.C.; Penha, R.E.S.S.; Suzuki, K.M.; Dec, E.; Gaglianone, M.C.; Alves-dosSantos, I.; Sofia, S.H. Phylogeography and historical demography of the Orchid Bee Euglossa iopoecila: signs of vicariant events associated to Quaternary climatic changes. Conserv Genet 2017, 18, 539-552, doi:10.1007/s10592-016-0905-7.

10. Heimpel, G.E.; de Boer, J.G. Sex Determination in the Hymenoptera. Ann Rev Entomol 2008, 53, $209-230$.

11. Zayed, A.; Roubik, D.W.; Packer, L. Use of diploid male frequency data as an indicator of pollinator decline. PNAS 2004, 271, doi:10.1098/rsbl.2003.0109.

12. Harpur, B.A.; Sobhani, M.; Zayed, A. A Review of the consequences of complementary sex determination and diploid male production on mating failures in the Hymenoptera. Entomol Experiment Appl 2013, 146, 156-164, doi:10.1111/j.1570-7458.2012.01306.x.

13. Zayed, A.; Packer, L. Complementary sex determination substantially increases extinction proneness of haplodiploid populations. PNAS 2005, 102, 10742-10746, doi:10.1073/pnas.0502271102.

14. Cook, J.M.; Crozier, R.H. Sex determination and population biology in the Hymenoptera. Trends in Ecology E Evolution 1995, 10, 281-286, doi:10.1016/0169-5347(95)90011-X.

15. Forbes, A.A.; Bagley, R.K.; Beer, M.A.; Hippee, A.C.; Widmayer, H.A. Quantifying the unquantifiable: why Hymenoptera, not Coleoptera, is the most speciose animal order. BMC Ecol 2018, 18, 21, doi:10.1186/s12898-018-0176-x.

16. Hein, S.; Poethke, H.J.; Dorn, S. What stops the "diploid male vortex"? A simulation study for species with single locus complementary sex determination. Ecol Model 2009, 220, 1663-1669, doi:10.1016/j.ecolmodel.2009.04.001.

17. Moure, J.S.; Melo, G.A.R.; Faria Jr., L.R.R. Euglossini Latreille, 1802. In Catalogue of Bees (Hymenoptera, Apoidea) in the Neotropical region - online version.; Moure, J.S., Urban, D., Melo, G.A.R., Eds.; Curitiba, 2012.

18. López-Uribe, M.M.; Zamudio, K.R.; Cardoso, C.F.; Danforth, B.N. Climate, physiological tolerance and sex-biased dispersal shape genetic structure of neotropical Orchid Bees. Mol Ecol 2014, 23, 1874-1890, doi:10.1111/mec.12689.

19. Pokorny, T.; Loose, D.; Dyker, G.; Quezada-Euán, J.J.G.; Eltz, T. Dispersal ability of male Orchid Bees and direct evidence for long-range flights. Apidologie 2015, 46, 224-237, doi:10.1007/s13592-014-0317-y.

20. Winkert, É.; de Oliveira, P.M.C.; Faria, L.R.R. Modeling diploid male dynamics in Hymenoptera: effects of the number of alleles, dispersal by random walk and simple spatial structuring. Physica A 2019, 524, 45-55, doi:10.1016/j.physa.2019.03.013.

21. Faria, L.R.R.; Soares, E.D.G.; Carmo, E. do; Oliveira, P.M.C. Diploid male dynamics under different numbers of sexual alleles and male dispersal abilities. Theor Biosci 2016, 135, 111-119, doi:10.1007/s12064016-0226-x. 
22. Soro, A.; Quezada-Euan, J.J.G.; Theodorou, P.; Moritz, R.F.A.; Paxton, R.J. The population genetics of two orchid bees suggests high dispersal, low diploid male production and only an effect of island isolation in lowering genetic diversity. Conserv Genet 2017, 18, 607-619, doi:10.1007/s10592-016-0912-8.

23. Boff, S.; Soro, A.; Paxton, R.J.; Alves-dos-Santos, I. Island isolation reduces genetic diversity and connectivity but does not significantly elevate diploid male production in a neotropical orchid bee. Conserv Genet 2014, 15, 1123-1135, doi:10.1007/s10592-014-0605-0.

24. Giangarelli, D.C.; Freiria, G.A.; Ferreira, D.G.; Aguiar, W.M.; Penha, R.E.S.; Alves, A.N.; Gaglianone, M.C.; Sofia, S.H. Orchid Bees: a new assessment on the rarity of diploid males in populations of this group of neotropical pollinators. Apidologie 2015, 46, 606-617, doi:10.1007/s13592-015-0350-5.

25. Myers, N.; Mittermeler, R.A.; Mittermeler, C.G.; da Fonseca, G.A.B.; Kent, J. Biodiversity hotspots for conservation priorities. Nature 2000, 403, 853-858, doi:10.1038/35002501.

26. Cortopassi-Laurino, M.; Zillikens, A.; Steiner, J. Pollen sources of the orchid bee Euglossa annectans Dressler 1982 (Hymenoptera: Apidae, Euglossini) analyzed from larval provisions. Genet Mol Res 2009, 8, 546-556, doi:10.4238/vol8-2kerr013.

27. Garófalo, C.A.; Camillo, E.; Augusto, S.C.; Jesus, B.M.V. de; Serrano, J.C. Nest structure and communal nesting in Euglossa (Glossura) annectans Dressler (Hymenoptera, Apidae, Euglossini). Rev Bras Zool 1998, 15, 589-596, doi:10.1590/s0101-81751998000300003.

28. Cortopassi-Laurino, M.; Hilário, S.D.; Ribeiro, M. de F.; Nogueira-Neto, P. Longevidade e tamanho de ninho gregário de Euglossa annectans em área urbana. In Proceedings of the Anals do VIII Encontro sobre Abelhas; 2008; p. 667.

29. Hijmans, R.J.; Cameron, S.E.; Parra, J.L.; Jones, P.G.; Jarvis, A. Very high resolution interpolated climate surfaces for global land areas. Int J Climatol 2005, 25, 1965-1978, doi:10.1002/joc.1276.

30. Warren, D.L.; Glor, R.E.; Turelli, M. ENMTools: A toolbox for comparative studies of environmental niche models. Ecography 2010, 33, 607-611, doi:10.1111/j.1600-0587.2009.06142.x.

31. Phillips, S.J.; Anderson, R.P.; Schapire, R.E. Maximum Entropy modeling of species geographic distributions. Ecol Model 2006, 190, 231-259, doi:10.1016/j.ecolmodel.2005.03.026.

32. VanDerWal, J.; Shoo, L.; Januchowski, S. SDMTools: Tools for processing data associated with species distribution modelling exercises. R Package Version 1.0. 2009.

33. Souza, C.M.; Z. Shimbo, J.; Rosa, M.R.; Parente, L.L.; A. Alencar, A.; Rudorff, B.F.T.; Hasenack, H.; Matsumoto, M.; G. Ferreira, L.; Souza-Filho, P.W.M.; et al. Reconstructing three decades of land use and land cover changes in Brazilian biomes with Landsat archive and earth engine. Remot Sens 2020, 12, 2735, doi:10.3390/rs12172735.

34. Paxton, R.J.; Zobel, M.U.; Steiner, J.; Zillikens, A. Microsatellite loci for Euglossa annectans (Hymenoptera: Apidae) and their variability in other Orchid Bees. Mol Ecol Resour 2009, 9, 1221-1223, doi:10.1111/j.17550998.2009.02612.x.

35. Penha, R.E.S.; Gaglianone, M.C.; Almeida, F.S.; Boff, S. v.; Sofia, S.H. Mitochondrial DNA of Euglossa iopoecila (Apidae, Euglossini) reveals two distinct lineages for this orchid bee species endemic to the Atlantic Forest. Apidologie 2015, 46, 346-358, doi:10.1007/s13592-014-0329-7.

36. Hegland, S.J.; Nielsen, A.; Lázaro, A.; Bjerknes, A.-L.; Totland, Ø. How Does climate warming affect plantpollinator interactions? Ecol Lett 2009, 12, 184-195, doi:10.1111/j.1461-0248.2008.01269.x.

37. Souza, R.O.; del Lama, M.A.; Cervini, M.; Mortari, N.; Eltz, T.; Zimmermann, Y.; Bach, C.; Brosi, B.J.; Suni, S.; Quezada-Euán, J.J.G.; et al. Conservation genetics of neotropical pollinators revisited: microsatellite analysis suggests that diploid males are rare in Orchid Bees. Evolution 2010, 64, 3318-3326, doi:10.1111/j.1558-5646.2010.01052.x.

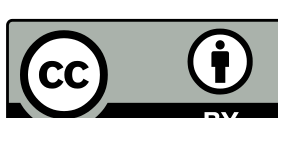

(C) 2020 by the authors; licensee MDPI, Basel, Switzerland. This article is an open access article distributed under the terms and conditions of the Creative Commons by Attribution (CC-BY) license (http://creativecommons.org/licenses/by/4.0/). 